\title{
A LATIN-AMERIKAI ORSZÁGOK NÉPSZÖVETSÉGI TAGSÁGÁNAK HATÁSA AZ EGYESÜLT ÁlLAMOK LATIN-AMERIKA POLITIKÁJÁRA
}

\author{
The Impact of Latin American League of Nations Membership \\ on the U. S. Policy Toward Latin America
}

\section{Nagy Gergely ${ }^{1}$}

\begin{abstract}
Absztrakt: A két világháború közötti időszak egyik kevésbé ismert története a latin-amerikai térség népszövetségi tevékenysége. A versailles-i békekonferencián életre hívott, nemzetek felett álló és azok egyenlőségén alapuló szervezet történelmi lehetőséget nyújtott a térség nemzetei számára. A szervezetet létrehozó Egyesült Államok belpolitikai csatározások miatt távol maradt a Népszövetségtől, így a latin-amerikai nemzetek számára először adódott komoly lehetőség arra, hogy az Egyesült Államok „védőernyője” alól kikerülve nyithassanak és kapcsolatokat létesíthessenek más, főleg európai nemzetekkel és véget vethessenek az USA Monroedoktrína nyújtotta intervenciós politikájának. A Népszövetséget megalapító országok egyharmada az amerikai kontinens nemzete volt, így a korszakban, Európa és a Távol-Kelet mellett, a latin-amerikai régió nemzetközi súlya is megnövekedni látszott. Latin-Amerika nemzetei a történelmi lehetőséggel viszont nem tudtak élni. Tanulmányomban ennek okait és problematikáját, valamint a latin-amerikai népszövetségi részvétel példákkal alátámasztott elemzését kívánom bemutatni, kitérve arra is, hogy az Latin-Amerika és a Népszövetség kapcsolatában az Egyesült Államok milyen viselkedést tanúsított.
\end{abstract}

\footnotetext{
${ }^{1}$ Nagy Gergely a Pázmány Péter Katolikus Egyetem Bölcsészet- és Társadalomtudományi Kar (PPKE BTK) Történelemtudományi Doktori Iskolájának doktorandusza, kutatási területe az első világháború utáni nemzetközi rend kialakulása. E-mail címe: gergely90.nagy@yahoo.com

A szerző további munkásságát lásd a Magyar Tudományos Művek Tára oldalán: https: $/ / \mathrm{m} 2 . \mathrm{mtmt}$.hu/gui2 $/$ ?type $=$ authors\&mode $=$ browse\&sel $=10070626$
} 
Kulcsszavak: Népszövetség, Latin-Amerika, Egyesült Államok, Monroedoktrína, Woodrow Wilson, izolacionalizmus, internacionalizmus

Abstract: The League of Nations' activities in Latin-America is one of the less known histories of the interwar period. The organization which stood above the nation-states brought about by the versailles peace process and which was based on equality offered a unique opportunity to the countries in this region. Although the United States' role was crucial in founding the League it subsequently remained distant from it due to domestic political issues. Thus Latin-American nations had for the first time the freedom to establish relations with other, mainly European countries without being overshadowed by the United States and their interventionist policies such as the Monroe-doctrine. The significance of the region seemed to increase, as signified by the fact that a third of founding nations for the League were from the Americas. Latin-America however could not seize this opportunity. In my research I will investigate the causes and problems related to this presenting several examples of Latin-American involvement with the League of Nations with emphasis on the role of the Unites States in this regard.

Keywords: League of Nations, Latin-America, United States, Monroedoctrine, Woodrow Wilson, isolationism, internationalism

\section{BEVEZETÉS}

Az első világháború merőben átalakította az addig ismert világot. Az európai nagyhatalmak által irányított nemzetközi élet megváltozott és azt többé már nem csak az „öreg kontinens” határozta meg. A Woodrow Wilson vezette Egyesült Államok 1917-ben csatlakozott a világháborúhoz és kész tervvel rendelkezett egy „új világ” megteremtésére, amely őrének a Nemzetek Szövetségét szánta. ${ }^{2}$ Az Egyesült Államok nemzetközi porondra lépésével az amerikai kontinens „latin” ajkú nemzetei számára is lehetôség nyílt a nemzetközi politikában való részvételre. Történelmük során először adatott meg, hogy az USA „védőernyője” alól kikerüljenek és más nemzetek felé nyissanak. A Népszövetség alapító tagjai között az európai országok mellett a latin-amerikaiak a szervezet tagjainak egyharmadát alkották. Az

${ }^{2}$ A Népszövetség elveiről lásd KIssingER, 2008. 35-46.o. 
amerikai elveken alapuló szervezetből viszont az Egyesült Államok kimaradt, így a szervezetben a latin-amerikaiak „nagy testvérük” jelenléte nélkül politizálhattak. A térség államai hiába törekedtek a Népszövetség nyújtotta történelmi lehetőség megvalósítására, azzal végül nem sikerült élni. $\mathrm{Az}$ 1920-as évtized közepétől Latin-Amerika nemzetei folyamatosan hagyták el a szervezetet és tértek vissza a korábbi pánamerikai együttműködéshez. ${ }^{3}$ Ennek problematikáját a Nemzetek Szövetségének „fogyatékosságával” szokták magyarázni, de ez jóval összetettebb folyamat volt.

\section{A NÉPSZÖVETSÉG MEGALAKULÁSA ÉS AZ AMERIKAI KONTINENS RÉSZVÉTELE}

A Ferenc Ferdinánd főherceg ellen elkövetett szarajevói merénylet az Osztrák-Magyar Monarchia és Szerbia közötti háborúhoz vezetett, amely napok leforgása alatt világháborúvá szélesedett és az európai kontinens legtöbb országa csatlakozott a világégéshez. ${ }^{4} \mathrm{Az}$ első világháború patthelyzetét az Egyesült Államok 1917-es hadba lépése oldotta fel és döntötte el az antant hatalmak javára. ${ }^{5}$ Az amerikai csatlakozás az antant oldalán történt, de nem annak tagjaként. A világháború során az antanthoz csatlakozó államokkal szemben az USA és a latin-amerikai országok, mint „szövetséges és társult” hatalmak léptek be a konfliktusba. Ez a megfogalmazás már előre sejtette, hogy az Egyesült Államok kész tervvel és világképpel rendelkezik a háborút követő rendezést illetően. Wilson egy új és igazságosabb világ megvalósítását tűzte ki céljául, amelyben minden nemzet egyenlő és a problémás kérdéseket többé nem háborúval, hanem egy ,igazságos” nemzetközi fórumon oldják meg. A béketeremtők között a wilsoni Nemzetek Szövetségének múködési mechanizmusa körül éles vita alakult ki. A szervezetet Wilson elnök, a francia és a brit delegáció különböző formában kívánta megalkotni. A Nemzetek Szövetségének alapokmányát végül az amerikaiak és a britek dolgozták ki, a munkálatokat pedig maga Wilson irányította. Az amerikai elnök mellett a dél-afrikai delegált, Jan Christian Smuts vállalta magára a munka oroszlánrészét. Kettejük tevékenykedése alapján született meg a Népszövetség egyezségokmányának tervezete. Természetesen a Nemzetek Szövetségének ilyen

\footnotetext{
${ }^{3}$ Peterecz, 2008. 136-137.o.

4 A szarajevói merénylet körülményeiről és az utána kialakuló júliusi válságról lásd CLARK, 2015. 379-561.o.

${ }^{5}$ Az amerikai részvételről ld. Bosco, 2007.
} 
formában történő megvalósulását és hatékonyságát sokan kétségbe vonták, de végül a wilsoni verzió került be a versailles-i békeszerződésbe. ${ }^{6}$

1919. június 28-án aláírt versailles-i békeszerződés mellett még aznap 44 ország képviselöje a Nemzetek Szövetségének egyezségokmányt is aláírta. Ahogy említettük, a Népszövetség Wilson iránymutatása és „bábáskodása” alatt született meg, így a mai napig tartja magát az a széles körben elfogadott nézet, hogy a szervezet alapvetően amerikai ötleten és elveken alapult, de a kép ennél árnyaltabb. ${ }^{7} \mathrm{Az}$ elnök gondolkodásmódjának szerves részét képezte az amerikai gondolkodás és politikai hagyomány, amellyel elnöksége előtti tudományos pályafutása során behatóan is megismerkedett. Wilson politikai világképe egyszerre épült jeffersoni és lincolni elvekre, de sokat merített az angolszász kultúrából és Otto von Bismarck munkásságából is. ${ }^{8}$

$\mathrm{Az}$ amerikai gondolkodástól nem állt távol a Nemzetek Szövetségében való részvétel és bár a Monroe-doktrínát az egyezségokmány 21. cikkelye elfogadta, az Egyesült Államok mégis távol maradt a szervezettől, amely a két világháború közti idôszakban súlyosan érintette annak múködését. Az USA távolmaradásának okai sokkal inkább voltak aktuálpolitikai csatározások következményei, mint a sokat emlegetett „izolacionalista” hangulat következménye. Pártállástól függetlenül az amerikai közvélemény és a politikusok többsége a párizsi békekonferencia után szembefordult az elnökkel, a versailles-i békeszerződés igazságtalanságai és az amerikai érdekek figyelmen kívül hagyása miatt. 1918-ban a szenátusban a republikánus párt szerzett többséget, és a Nemzetek Szövetségének sok vita után megszületett alapokmányát a békekonferencia a békeszerződés részeként tartotta számon, így az amerikai alkotmány értelmében azt, a békeszerződéssel együtt, a szenátusnak is jóvá kellett hagynia. A szenátorok többsége is kész volt elfogadni az Egyesült Államok új szerepvállalását, de nem olyan formában, ahogy azt Wilson elképzelte. A szenátus által javasolt változtatásokat, amelyeket a britek és franciák is támogattak, viszont az elnök nem volt hajlandó elfogadni, ugyanis a védnöksége alatt létrehozott szervezetre úgy tekintett, mint az Ószövetségre, amelyen emberi kéz már nem változtathat. A szenátus tehát nem fogadta el a Wilson-féle Népszövetséget, de változtatások árán

${ }^{6}$ A párizsi békekonferencián a Népszövetségről kialakult vitáról vö. MACMILLAN, 2005. 120-138.o. KISSINGER, 2008. 217-241.o.

${ }^{7}$ KISSINGER, 2008. 218.o.

8 GOLDBERG, 2012. 87-88.o. 
hajlandó lett volna abban részt venni. A szervezet wilsoni tervezetét a szenátus szavazta le, a szenátus által javasolt változtatások három verzióját pedig maga Wilson elnök vétózta meg. Az Egyesült Államok tehát nem az izolacionalista hangulat miatt maradt távol a Nemzetek Szövetségétől, hanem Wilson kompromisszumkészségének hiánya miatt. ${ }^{9}$

Az Egyesült Államok távolmaradása mellett kevésbé ismert történet a latin-amerikai országok népszövetségi részvétele. Az első világháborúhoz, jellemzően nem sokkal a német fegyverszünet előtt, számos latin-amerikai nemzet csatlakozott. A világháború fegyveres harcaiba döntő szerepet már nem játszottak. A világháborúhoz való csatlakozásuk jellemzően két táborra oszlik. Az első latin-amerikai államok nem sokkal az Egyesült Államok hadüzenete után csatlakoztak a konfliktushoz, míg a másik csoportja csak 1918 áprilisa és júliusa között szánta el magát a Németországnak küldött hadüzentre. ${ }^{10}$ Felmerülhet az a kérdés, hogy a latin-amerikaiak milyen megfontolásból csatlakoztak a világégéshez. A Wilson elnök által meghirdetett háború utáni új nemzetközi rendbe így remélték helyüket biztosítani. A Népszövetségbe a győztes hatalmak és az első körben csatlakozni kívánó semleges országok automatikus meghívást kaptak, így nem kellett átesniük a hosszadalmas és kétes kimenetelű tagsági próbán. A később csatlakozni kívánó nemzetek számára a népszövetségi felvétel feltételekhez volt kötve, amelyek között az is számított, hogy milyen az adott ország nemzetközi múltja, viselkedése, vagy belpolitikai berendezkedése. $^{11}$ A latin-amerikaiak ezért csatlakoztak az első világháborúhoz. Névleges részvételükkel együtt népszövetségi tagságot nyertek. $^{12}$

\section{A NEMZETEK SZÖVETSÉGE ÉS LATIN-AMERIKA}

Az első világháború után a győztes hatalmak által felállítani kívánt új nemzetközi rend egyik alapköve a Népszövetség volt. A szervezet elvileg hivatott volt egyenlő mértékben képviselni minden nemzetet. Ez az elméletben azt jelentette, hogy az új nemzetközi fórumon a résztvevő tagok méretük, földrajzi elhelyezkedésük, vagy a világpolitikában betöltött

\footnotetext{
${ }^{9}$ vö. JOHNSON, 2016. 642-649.o. MAGYARICS, 2014. 208-218.o.

10 A latin-amerikai országok hadüzenetéről a statisztikát ld. SZIJ - RAVASZ, 2000. 743744.o.

11 Mengele, 1927. 23. 115.o.

12 Peterecz, 2008. 130.o.
} 
A latin-amerikai országok népszövetségi tagságának hatása az Egyesült Államok LatinAmerika politikájára

súlyuktól függetlenül egyenlő elbírálásban részesültek. A szervezet idealista felépítése azt is lehetővé tette, hogy a részt vevő tagok új kapcsolatokat létesítsenek más szövetségi tagokkal. Ahogy egy korabeli kubai lap fogalmazott a térség népszövetségi reményeirôl: „az idő nemcsak az európai, hanem az amerikai kis nemzetek számára is eljött [...].",13

\subsection{LATIN-AMERIKA SÚLYA A SZERVEZETEN BELÜL}

Mindezek fényében érthető, hogy a latin-amerikaiak történelmi lehetőségként tekintettek a Népszövetségre. Ahogy említettük az alapító és első körben meghívott nemzet egy jelentős része a latin-amerikai térség képviselője volt. A $43^{14}$ országból 17 volt az említett régió képviselője, ami a szervezetben résztvevő országok egyharmadát jelentette. Megalakulásakor a Nemzetek Szövetsége egy „háromlábú” szervezethez hasonlított, amelynek pilléreit már nemcsak az európai kontinens adta, hanem Latin-Amerika és a Távol-Kelet is. Ez a lehetôség pedig egyértelműen kedvezett LatinAmerikának és a történelem során először tűnt úgy, hogy a térség nemzetközi súlyra emelkedhet. A Népszövetség indulásakor Latin-Amerika „függetlenséget” élvező országai, a később csatlakozó Dominikai Köztársaság, Ecuador és Mexikó kivételével, szinte mind tagjai voltak. Ha Kanadát is számoljuk, akkor az Egyesült Államok kivételével szinte az egész amerikai kontinens részt vett a szervezet müködésében, szemben Európával, ahonnan sokáig meghatározó államok hiányoztak. ${ }^{15}$

A Nemzetek Szövetségének múködését az említett három térség egyensúlyára építették. A Népszövetség három fő szervezetre épült, ami elvileg a mûködését volt hivatott biztosítani. A fő döntéshozó szervet, a Tanácsot az állandó tagok mellett az időként változó, és véletlenszerűen kiválasztott, ideiglenes tagok alkották, a Közgyúlésben minden tagnak volt delegáltja, Titkárság pedig a Szövetség hivatalos vezetőjének ,irodája” volt. A Tanács állandó tagjai között a kor nagyhatalmait találhatjuk, ahol természetesen túlsúlyban voltak az európai nagyhatalmak. Eredetileg öt állandó tag alkotta volna a tanácsot, három európai-, Nagy-Britannia, Franciaország, Olaszország, egy távol-keleti nagyhatalom, Japán, és az amerikai kontinenst képviselni hivatott Egyesült Államok. Az USA helye

\footnotetext{
13 Idézi: MCPHERSON, 2015. 24.o.

14 A Nemzetek Szövetségének egyezségokmányát eredetileg 44 ország írta alá, de a szervezet az Egyesült Államok kimaradásával, működését 43 országgal kezdte meg.

15 United NATIONS OfFiCE AT GENEVA, 2020.
} 
annak kimaradásával viszont üresen maradt, és az ötödik amerikai tag helye betöltésre vált. Erre a legjobb eséllyel Brazília pályázott, elhelyezkedése, méretei és a korban az Egyesült Államokkal kialakított jó kapcsolatai miatt, de a Népszövetség európai hatalmai ezt folyamatosan megvétózták. Brazília ennek hatására már 1926-ban elhagyta a szervezetet, de utána is folyamatosan felvetődött az az igény, hogy az ötödik helyet a latin-amerikai országok valamelyikének kellene betöltenie, de ettôl az európai tömb továbbra is elzárkózott és inkább az ideiglenes tagok számát növelte. A vázolt példa jól mutatja, hogy a Tanácsban Latin-Amerika egyenlő súlyra emelése az európai hatalmak ellenállásba ütközött. Mexikó késői csatlakozása meglepő tényként hathat, de az első világháború előtt elmérgesedett amerikai-mexikói viszony erre is magyarázatot ad. Wilson elnök külön kérésére Mexikó nem kapott meghívást, és csak hosszas procedúra után 1931-ben vették fel. ${ }^{16}$ Érdemes még Argentína „részvételt” is kiemelni. Brazilia mellett, Dél-Amerika másik hangsúlyos országa bár az alapítók között csatlakozott a szervezethez, de igazán annak jelentős tagja sose tudott lenne. Az egymást követő argentin belpolitikai válságok hatására 1921-ben a Népszövetség visszavonta az argentin tagságot, és azt csak 1933ban állította vissza. ${ }^{17}$

\subsection{LATIN-AMERIKA NÉPSZÖVETSÉGI CÉLJA ÉS TEVÉKENYSÉGE}

Az első világháború utáni évtizedben a latin-amerikaiak célja egyértelműen a régió „amerikai védőernyő” aluli kimozdítása volt. Az Egyesült Államok kimaradásával ez a lehetôség elérhetőnek tűnt, igaz a Népszövetség 21. cikkelye továbbra is érvényben tartotta a Monroedoktrínát, amely alapján az USA továbbra is „bábáskodhatott” a régió felett. A Monroe-doktrína nyújtotta beavatkozási lehetőség szembe ment a népszövetség alapelveivel, amelyre a latin-amerikai képviselők igyekeztek rámutatni. A doktrína körüli vita tisztázására a legnagyobb erőfeszítést Costa Rica tette, de ezt az európai irányítás alatt álló szervezet továbbra sem kívánta megváltoztatni, aminek hatására Costa Rica 1925-ben elsőként lépett ki a Népszövetségből. Ennek okai egyszerűen azok voltak, hogy az európai nagyhatalmak nem kívánták magukra haragítani az Egyesült Államokat. Az USA hivatalosan izolacionalista politikát követett, de valójában igen aktív

${ }^{16}$ KANE, 1973. 337.o.

17 DugGan, 1934. 284-285.o. 
gazdasági eszközökön alapuló külpolitikát folytatott. ${ }^{18}$ Az első világháború során az amerikaiak által az európai antant országoknak nyújtott kölcsönök visszafizetésének feltételeirôl tárgyalások folytak, ahol az európaiak a kedvező feltételek kialkudásában voltak érdekeltek, ennek pedig elengedhetetlen feltétele volt, hogy ne keveredjenek olyan diplomáciai ügybe, amely az Egyesült Államokkal szembeni konfliktusba torkolhat. Az európaiak, a gazdasági tárgyalások mellett, a nemzetközi politikában is tárgyalni kényszerült az USA-val. ${ }^{19}$ Nagy-Britannia és az Egyesült Államok stratégiai együttműködése kikristályosodni látszott, amelyet a britek érthetô okokból nem kívántak terhelni egy esetleges USA ellenes népszövetségi tevékenységgel. Ilyen lett volna, ha a Nemzetek Szövetsége a Monroedoktrína nyújtotta előnyöket a kétségbe vonja, vagy Brazília - esetleg más latin-amerikai ország - állandó taggá emelésével a térség nemzetközi súlyát tovább emelik. ${ }^{20}$ A Benito Mussolini vezette fasiszta Olaszország szintén az Egyesült Államok stratégiai partnerségét kereste. Az fasiszta Olaszország igyekezett megnyerni az USA-t az olasz külpolitikai érdekek és gazdasági újjáépítés támogatására. Olaszország ezért szintén nem kívánt a konfliktusba keveredni az Egyesült Államokkal, amit jól bizonyít, hogy az USA-ban élő olasz anarchisták, és az olasz bevándorlás szigorítása ügyében Mussolini hivatalos diplomáciai csatornákon nem emelte fel a hangját. ${ }^{21}$ A duce vezette Olaszország továbbá az Egyesült Államok népszövetségi tagságát is támogatta és közvetítő szerepet ajánlott az ügyben, amit végül nem sikerült elérni. A latin-amerikaiak legjelentősebb támogatója Franciaország volt. Saját ügyeinek támogatására a francia diplomácia ezzel kívánta megnyerni az említett régió államait. A francia diplomácia, a kisantanton kívül, a Népszövetségben a latin-amerikai államok támogatásával járó szavazatokat kívánta megszerezni. ${ }^{23}$ Összességében elmondható, hogy az Egyesült Államokkal való együttműködés érdekében az európai nagyhatalmak a Népszövetségen belül nem kívánták a Latin-Amerikát egyenlő erőre emelni, vagy a Monroe-doktrínát ugyanitt megkérdőjelezni. Ettől függetlenül az európai nagyhatalmak a latin-amerikai nemzetek céljait olyan ügyekben sem

\footnotetext{
18 IRIYE, 1993. 88-103.O.

19 MAgYarics, 2014. 254-288.o.

${ }^{20}$ JOHNSON, 2016. 766.o.

${ }^{21}$ CANNISTRARO, 1996. 31-62.o.

22 Az első világháború utáni évtizedben Olaszország és az Egyesült Államok viszonyáról bővebben ld. MigONE, 2015. 28-170.o.

23 WEHRLI, 2015. 2.o.
} 
voltak hajlandóak támogatni, amely nem befolyásolta, vagy egyáltalán nem is érintette az USA-val folytatni kívánt viszonyukat. ${ }^{24}$

A Nemzetek Szövetségére ettől függetlenül a latin-amerikaiak stratégiai fontossággal tekintettek. A népszövetségi részvétel, lehetőséget adott arra, hogy a szervezet nyújtotta új diplomáciai csatornákon utat nyissanak az európai országok felé történő együttmúködésnek. Ezt jól foglalta össze Gonzalo Zaldumbide ecuadori külügyminiszter 1930-ban kelt jelentése: „két pólus tolhatja el vagy egyensúlyozhatja ki sorsunkat a régi és új világ lefolyása kö̈ött: Washington és Genf. ${ }^{\text {,25 }}$ Alapvetően jellemző volt, hogy a kisebb latin-amerikai államok tanúsítottak nagyobb aktivitást a szervezetben, ami szintén csökkentette a régió nemzeteinek hatékony érdekérvényesítését. Brazília korai kivonulásáról, Mexikó késői csatlakozásáról és az argentin tagság felfüggesztéséről már ejtettünk szót, de Bolívia és Peru részvétele is sokáig csak formális volt. A két ország alapító tagként hivatalosan a Nemzetek Szövetségének kötelékébe tartozott, de az egymás között folyó határvita miatt 1929-ig ülésein képviselőik nem vettek részt. ${ }^{26}$ A Nemzetek Szövetsége már a kezdeti időszakában is az európai ügyekkel foglalkozott, míg Latin-Amerika ügyét rendre háttérbe szorították. A szervezet fórumain próbálták felhívni a figyelmet arra, hogy a Nemzetek Szövetségének hangzatos elve, miszerint többé a „kis államok” is egyenlők, mindössze csak üres frázisok. ${ }^{27}$ Manuel Arocha venezuelai népszövetségi képviselő már 1922-ben a következőket jelentette a szervezet múködéséről: „Egy átlag latinamerikai polgár számára a Nemzetek Szövetsége, [...] amely igérettel és reményekkel teli napokat igér [...] nem léterik. Ebböl a szempontból itt Genfben ennek az. idealisqutikus projektnek a karikatúráját léterik: az európai nemzetek közössége, amelyet a nagyhatalmake érdekei szerint kezelnek, egójuk és bosszúvágyuk kielégitésére basználnak, ami rengeteg pénz̧be kerül, és semmilyen elönnyel nem jär az elhanyagolt latin-amerikai térség számára. Másfelól viszont egy átlagos népszövetségi képviseló számára Latin-Amerika egy kicsi és távoli országok csoportja, amelyek nem akarnak fizetni, és amelyek folyamatosan vitában állnak egymással."28 Jelentéséből kitűnik Latin-Amerika népszövetségi problematikájának összetettsége: az európai országok elutasító magatartása és az együttműködés hiánya. Archola egy kevésbé ismert tényre ugyancsak felhívja a figyelmet: a latin-amerikai

\footnotetext{
24 MCPHERSON, 2015. 23.o.

25 Idézi: WEHRLI, 2015. 1.o.

${ }^{26}$ Uo. 2.o.

${ }^{27}$ MCPHERSON, 2015. 23-24.o.

28 Idézi: WeHrLI, 2015. 3.o.
} 
nemzetek fizetésképtelenségére. Ez végig kísérte a Latin-Amerika „életét”, így nemzetközi törekvéseikre is hatással bírt. A 19. század során azon latinamerikai konfliktusok, amelyek az európai nagyhatalmak és az Egyesült Államok érdekeltségeit is érintette, és azok beavatkozásához vezetett, nagy többségben az elmaradó kölcsönfizetések, vagy gazdasági-, kereskedelmi és üzleti érdekek sérülése miatt történt. ${ }^{29}$ A népszövetségi céljaik elérésének egyik nagy akadálya újfent a fizetésképtelenség volt. Ettől függetlenül a Nemzetek Szövetségének első vezetője, Sir Eric Drummond, külön irodát hozott létre a térség ügyeinek kezelésére. ${ }^{30}$

Az 1920-as évtized második felétôl a Nemzetek Szövetségéből kiábránduló latin-amerikai országok sorra hagyták el a szervezetet. A gazdasági világválság hatására megváltozó nemzetközi helyzet a Népszövetség addig se ígéretes múködését is lassú halálra ítélte. 1931-ben a Távol-Keleten Japán a kínai polgárháborús viszonyokra hivatkozva bevonult Mandzsúriába, ami a Népszövetségben súlyos válságot idézett elő és Japán kilépésével végződött. A népszövetségi tagságot 1926-ban elnyerő és ezzel az első világháború utáni nemzetközi életbe rehabilitált Németország Hitler hatalomra jutása után szinte azonnal, 1934-ben kilépett a szervezetből. Olaszország az etiópiai válság hatására, 1937-ban hagyta el a Nemzetek Szövetségét. A szervezet jelentős európai nagyhatalmakat vesztett el, és a Tanács állandó tagjai négy főről kettőre csökkent. ${ }^{31} \mathrm{Az}$ említett konfliktusok viszont a még népszövetségi tagsággal rendelkező latinamerikai államokat is érintette. Tanulva az előző évtized hibáiból, immár nem tanúsítottak passzivitást, hanem hangjukat hallatva próbáltak aktív résztvevői lenni a szervezet válságos óráinak. A latin-amerikaiak, élükön Mexikóval, elítélték a népszövetségi elveket megsértő japán és olasz magatartást, igaz az etióp válság során olasz érdekeltségekkel rendelkező latin-amerikai nemzetek, mint Argentína, Peru, vagy Venezuela, nem csatlakoztak az olasz ellenes táborba. Ettől függetlenül a latin-amerikaiak kivétel nélkül betartották a Népszövetség által Olaszországra kiszabott gazdasági szankciókat és az olajembargót. ${ }^{32}$ A mai napig tévesen úgy él a köztudatban, hogy a krízis során a szankciókat és az embargót NagyBritannia nyomására lépte meg a szervezet. A gazdasági szankciókat valóban

29 Az Egyesült Államok Latin-Amerikában tanúsított intervenciós politikájáról lásd MAGYARICS, 2014. 83-89.o. 116-149.o.

30 WEHRLI, 2015. 6-7.o.

31 A Népszövetség 1930-as évekbeli válságáról lásd TAYLOR, 2011. 92-141.o.

32 vö. WEHRLI, 2015. 33-48.o. LEÓN, 2015. 49-62.o. 
a britek tanácsára vezették be, de az olajembargót Anthony Eden külügyminiszter javaslatára elvetették. ${ }^{33} \mathrm{Az}$ olajembargó bevezetését Franklin D. Roosevelt elnök nyomására vetették be a britek a Népszövetséggel. Amíg az olajembargó a latin-amerikai államoknak, akik a korban jelentős olajkitermeléssel rendelkeztek, mint Venezuela, vagy Mexikó, hatalmas érvágást jelentett, addig ez népszövetségi távolmaradása miatt az Egyesült Államokra nem vonatkozott. Roosevelt elnök természetesen az Olaszország felé történő az amerikai állami olajszállítást minimálisra csökkentette, de a magánkézben lévő amerikai olajkitermelő óriások az állami megkötés alól mentesültek. A világban tapasztalható embargó hatására amerikai olajcégek szinte egyedül láthattak el az olasz háborús olajszükségleteket. ${ }^{34}$

A spanyol polgárháború során beavatkozó európai nagyhatalmak elitélése ellen Mexikó tette a legnagyobb erőfeszítéseket, de az akkor már „tetszhalott” állapotban lévő Népszövetség az ügyben semmit sem tett. A spanyol polgárháború során a latin-amerikai országok népszövetségi aktivitása egyértelmûen az intervenciós politika elleni állásfoglalásnak volt betudható. Az Egyesült Államok korábbi „viselkedése” miatt történelmük során többször, saját „bőrükön” tapasztalták ennek hátrányát és álszentségét. Ezt jól bizonyítja, hogy a spanyol polgárháború eseményeit Mexikó a népszövetségi fórumokon, Wilson elnök országuk ellen vezetett fegyveres beavatkozással vonta párhuzamban. Rámutattak arra, hogy amíg Európában az első világháború javában dúlt, addig Mexikóban a köztársaság forradalmi csoportokkal volt kénytelen harcba szállni, az Egyesült Államok pedig az általa támogatott forradalmi csoportokat fegyverekkel látta el, majd mellettük többször beavatkozott. Mexikó rámutatott arra, hogy Wilson érvelése is azon alapult, hogy csak szomszédja, Mexikó érdekei miatt avatkozik be. Az amerikai elnök tette ezt akkor is, amikor a hatalmon lévő köztársasági elnököt amerikai katonai felügyelet mellett megtartott választáson újra megválasztották. Wilson viszont nem a választás során győztes jelöltet támogatta, így csak idô kérdése volt egy újabb intervenció, ami meg is történt. A Mexikó ezzel a Spanyolországba fegyverek és „önkéntes” csapatok küldésével beavatkozó olasz, német és szovjet stratégia lényegére kívánt rávilágítani. ${ }^{35}$

\footnotetext{
33 TAYLOR, 2011. 133.o.

${ }^{34}$ Franklin D. Roosevelt olasz az etióp válság idején tanúsított viselkedésérôl lásd MiGONE, 2015. 287-388.o.

35 OÑATE, 2015. 63-79.o.
} 


\subsection{AZ EGYESÜLT ÁLLAMOK FURCSA IZOLACIONALIZMUSA}

A Latin-Amerika népszövetségi céljainak meghiúsulásának másik fő oka az Egyesült Államok Népszövetségre gyakorolt nyomása volt. A történetírás az elsô világháború utáni évtizedre úgy tekint, hogy az USA visszahúzódott a nemzetközi politikától, és elzárkózva a világ ügyeitől, izolacionalista politikát folytatott. A korban valóban tapasztalható volt egy ilyen közhangulat, de a Wilson után megválasztott republikánus adminisztrációk egyáltalán nem voltak izolacionalisták. A republikánus párt egy része valóban izolacionalista politikát képviselt, de a kormányzatra kerülő Warren G. Hardin, majd az őt követő Calvin Coolidge is a republikánusok internacionalista ágához tartozott. ${ }^{36}$ A Harding- és Coolidge-adminisztráció felismerte a Népszövetség Latin-Amerika számára adta történelmi lehetőséget. A párizsi békekonferencián már Wilson közeli tanácsadója és barátja, Edward House ezredes is figyelmeztette az elnököt, hogy a latin-amerikaiak népszövetségi invitálása egyet jelenthet a régió az amerikai „védőernyő” alóli kikerülésével. ${ }^{37}$ Wilson elnök ettől nem tartott, ugyanis hitt abban, hogy a Népszövetségben a latin-amerikai nemzetek az Egyesült Államok bázisa lesz. Wilson hibáját sokan szűklátókörűségének és naivitásának számlájára írták. A valóságban azonban az elnök Nemzetek Szövetségének tervébe ez tökéletesen beleillet. Az új rendszer szerint minden nemzet egyenlő volt, így az Egyesült Államok az európai országokkal szemben csak egy ország volt, a latin-amerikai országokkal kiegészülve viszont már hasonló erőt képviselt. Wilson bizakodása az latinamerikai államok támogatására szintén nem volt alaptalan. Bár elnöksége alatt az Egyesült Államok és a térség államainak kapcsolata - néhány kivételtôl eltekintve - történelmi mélypontra kerültek, de Wilson elnök nem egyszer bebizonyította, hogyha Latin-Amerika nemzetei nem kívánnak az Egyesült Államokkal együttmúködni, akkor kész katonai erőhöz fordulni és akár megszállás, vagy protektorátus alatt tartani a régió nemzeteit. House ezredes figyelmeztetésének idején, 1919-ben, az USA öt közép-amerikai és karibi országot tartott katonai megszállás alatt. ${ }^{38}$ Wilson nem naiv volt, mindössze pontosan tudta azt, amit a kortárs Fabio Fiallo dominikai költő is megfogalmazott: „Wilson cinizmussal folytatta párhuzamos hazugságait, amikor Versailles-ban kineveaték a gyenge nemzetek, jogainak védelmezöjévé, miközben itt a

\footnotetext{
36 JOHNSON, 2016. 646., 763-771.o.

${ }^{37}$ MCPHERSON, 2015. 22.o.

38 A statisztikák forrása (térképes szemléltetéssel): MAGYARICS, 2014. 712.o.
} 


\section{karibi térség vizeit befedte tengerészgyalogosokkal és katonákkal teleasúfolt rombolókekal. ${ }^{39}$}

Bár az Egyesült Államok kimaradt a Népszövetségből, de az 1920-as évtized amerikai kormányzataihoz köthető szakemberek magánjelleggel szervesen részt vettek, tanácsot adtak, segítették vagy irányították a szervezetet. Ezek mellett az USA kormányzatai hallgatólagosan támogatta a Népszövetség munkáját. A washingtoni konferencia az Egyesült Államok irányítása alatt folyt le, de a konferencián a nagyhatalmak mellett, Harding elnök engedélyével, a csendes-óceáni és távol-keleti birtokokkal rendelkező és a vitás kérdésekben érdekelt, más európai országok is részt vehettek. Az amerikai diplomácia mindezek mellett gesztusként megadta, hogy a konferencián megkötött egyezmények nemzetközi hatályra emelkedésének aktusát a Nemezetek Szövetsége végezhette el. Cserébe az Egyesült Államok a Latin-Amerikával szemben folytatott politikájában tanúsított népszövetségi passzivitást és a Monroe-doktrína elismerését várta el. $^{40}$ Ahogy arról már szó esett az USA népszövetségi tagságáról az európai nagyhatalmak és maga a Nemzetek Szövetsége sem tett le, amit jól bizonyít, hogy az ötödik állandó tagsági helyet fenntartották az USA számára. A latin-amerikaiak törekvései, hogy a Nemzetek Szövetsége segítsen az amerikai megszállás és uralom véget vetésének, süket fülekre találtak. Ebben az ügyben a legaktívabb diplomáciát a közép-amerikai és karibi országok folytattak. Érdemes kiemelni a haiti diplomata és történész Dantès Bellegarde-t, aki a régió ügyében kétoldalú diplomáciai tárgyalásokat is folytatott. Reálpolitikai megfontolásokból természetesen Franciaországban kereste ezt a szövetségest. A francia diplomáciában megvolt a hajlandóság a latinamerikai ügyek támogatására, de a kérdésben egyedüli nagyhatalomként ők sem kívántak az Egyesült Államokkal szembe fordulni. ${ }^{41}$ Diógenes Escalante, aki 1920-1936 között a venezuelai népszövetségi delegáció vezetője volt, már 1921-ben erről a problémáról írt Juan Vincente Gómez elnöknek: „A Szövetség jövöben sqámunkera azt a célt szolgálhatja, hogy az Egyesült Államok mindent elszivó befolyásának ellensúlyozza, és együtt dolgoz̧atunk az. európaiakekal annak érdekében, hogy közös politikánkat minél jobban megfogalmazzuk. Ez egyile okea, hogy az. USA nem szereti a Szövetséget, mert az elmozdítja a délamerikai köztársaságokat $W$ ashington gyámsága alól, köz̧ben nekünk nemzettöżi

\footnotetext{
${ }^{39}$ Fiallo, 1940. 19.o.

40 STREETER, 2010. 127-128.o.

${ }^{41}$ MCPherson, 2015. 27.o.
} 
A latin-amerikai országok népszövetségi tagságának hatása az Egyesült Államok LatinAmerika politikájára

jelentöséget ad, és az. Egyesült Allamok jobban szeretné jobban szeretné ha ez az. érettségünk nem lenne meg. ,

Az USA külpolitikájának egyik fó vonala a korban egyértelműen arra irányult, hogy a Latin-Amerika nemzeteit rövid határidőn belül kivonja a népszövetségi felügyelet alól, és azok újra az amerikai „védőernyő” alá kerüljenek. A Nemzetek Szövetségét és képviselőit nemcsak az Egyesült Államok és a latin-amerikai térség konfliktusiba nem engedték be, hanem az egymással vívott konfliktusokba se, még akkor sem, ha mindkét fél népszövetségi tagsággal rendelkezett. ${ }^{43}$ Amíg az amerikaiak kimaradásuk ellenére részt vettek a Népszövetség ügyeiben, az 1923-as santiagói és az 1928-as havannai Pán-Amerikai Konferenciákról a népszövetségi képviselők ki voltak tiltva. ${ }^{44}$ Az Egyesült Államok külpolitikája Latin-Amerikával szemben is irányt váltott. A közép-amerikai és karibi térségben, két kivételtôl eltekintve, nem nyúltak intervenciós eszközökhöz, és ha tehették kerülték a nyílt fegyveres beavatkozásokat. A katonai megszállások és protektorátusok nagy részét az 1920-as évtized végére felszámolták, és már csak Nicaragua és Haiti volt az Egyesült Államok megszállása, Panama, Kuba és a Dominikai Köztársaság pedig annak protektorátus alatt. ${ }^{45}$

A Harding- és Coolidge-adminisztráció alatt tapasztalható „visszavonulás” megint nem az izolacionalista külpolitikájuk terméke volt. Az 1920-as évek amerikai politikája a latin-amerikai térségben gazdasági erejét használta fel érdekei érvényesítésére. A „dollárdiplomáciának” is nevezett külpolitikai doktrína Európában ez az Egyesült Államok kereskedelmi kivitelének és az új befektetések megvalósításának célját szolgálta, Latin-Amerikában pedig a térség országait az Egyesült Államok „védőernyője” alatt kívánta tartani. Igaz a Népszövetség nyújtotta új nemzetközi rendben nem vettek részt, de a korábbiakkal ellentétben az USA „békésebb” eszközökkel folytathatta érdekérvényesítését. Ezt bizonyítja a latin-amerikai országok irányában tanúsított újfajta viselkedése is, amely során a katonai beavatkozásokat lassan felváltották a gazdasági és pénzügyi beavatkozások. Ez utóbbinak a latin-amerikai nemzetek számára nemcsak

\footnotetext{
42 Idézi: EwELL, 1996. 127.o.

43 Ez alól kivétel volt az 1932-ben a Kolumbia és Peru között Letícia hovatartozásának okán kitört fegyveres konfliktus. A Népszövetség 1933-ban egy kisebb békefenntartó csapatot küldött az érintett területre. A vita közel egy évig folyt a Szövetségben, és a Nemzetek Szövetsége végül Kolumbia javára ítélte a várost.

${ }^{44}$ Burks, 1959. 891.o.

45 A statisztika forrása: MAGYARICS, 2014. 712.o.
} 
az volt az előnye, hogy a térségből az Egyesült Államok katonái fokozatosan eltűntek, hanem az adott államok gazdasági stabilitásának biztosításával a politikai stabilitás is megnőtt. A latin-amerikai államok ezeket az előnyöket is figyelembe véve folyamatosan léptek ki a Népszövetség kötelékéből és tértek vissza a „pánamerikai” együttmúködéshez. Franklin Roosevelt hatalomra jutásáig a latin-amerikaiak a pánamerikai konferenciákon több eredményt értek el, mint a népszövetségi tagságuk során valaha. Franklin Roosevelt elnök 1933-as megválasztása után meghirdetett jó szomszédság elve egy hosszabb folyamat eredménye volt, amelyet az elsô világháború utáni évtized amerikai külpolitikája kezdett meg. ${ }^{46}$

\section{KONKLÚZIÓ}

Az első világháború után olyan új nemzetközi rend volt kialakulóban, ahol a Latin-Amerika nemzetközi súlya is megemelkedni látszott. A latinamerikai nemzetek számára először nyílt lehetőség arra, hogy érdekeiket és céljaikat érvényesíthessék. A Népszövetség keretében a régió országinak együttes törekvése volt, hogy térségük kikerüljön az Egyesült Államok „védőernyője” alól, és a szervezet nyújtotta új diplomácia csatornákon keresztül nyithassanak és kapcsolatot építhessenek más, főleg európai nagyhatalmakkal. A latin-amerikaiak közös célja volt továbbá az Egyesült Államok térségben tanúsított „intervenciós” politikájának és a Monroedoktrínai népszövetségi elítélésének elérése. A Nemzetek Szövetsége nyújtotta történelmi lehetőséggel viszont a régió országai nem tudtak élni. Az európai nagyhatalmak vezette Népszövetség már megalakulása után európai liga jellegét öltötte. A Népszövetség igazán soha nem tanúsított aktivitást a latin-amerikai régió ügyeivel kapcsolatban. Az Egyesült Államok tagsága nélkül a latin-amerikaiak a népszövetség intézményein keresztül nem tudták Washingtont arra kényszeríteni, hogy bármilyen változást eszközöljön a latin-amerikai régióban tanúsított politikáján. A Nemzetek Szövetsége csak retorikus eszközként szolgált, ahol a latin-amerikaiak felszólalhattak és problémáikat a világ elé tárhatták, de az USA részvétele nélkül azt megoldani nem tudták. Az Egyesült Államok hallgatólagos támogatása, amit a Nemzetek Szövetsége számára későbbi években nyújtott, igazából a latin-amerikaiak népszövetségi tagsága ellen irányult. Ahogy a fentebbi fejezetekben is láthattuk Washington nyomást gyakorolt az európai

46 Peterecz, 2008. 136-137.o. 
nagyhatalmakra, hogy ők és a Nemzetek Szövetsége kerülje el az amerikai féltekének vitás ügyet, hisz ez csak periféria szemben a Népszövetség „,nagyobb” küldetéseivel szemben. Az Egyesült Államokkal pedig az európaiak a tanulmányban bemutatott különböző okokból nem kívántak vitába keveredni egy olyan térségben, ahol kevésbé érvényesülhetett befolyásuk. A latin-amerikaiak tehát egyszerre szenvedtek az Egyesült Államok Népszövetségre gyakorolt nyomásától és attól, hogy Washingtont nem lehetett rávenni a szervezet határozatainak és rendelkezéseinek betartására. ${ }^{47}$

Az európai nagyhatalmak és nemzetek többsége szintén passzivitással tekintett a régió ügyeire. Többségük jelentős összegekkel tartozott az Egyesült Államoknak, de a korban a legtöbb európai nagyhatalom az USA kegyeit kereste, hogy annak befektetései vagy stratégiai támogatását elérjék, ezért senki sem kívánta kihívni az „amerikai kolosszust.” Az első világháborús pusztítás hatására az európai nagyhatalmak tekintélye sokat vesztett régi fényéből, amely megtartásához még görcsösen ragaszkodtak, így féltékenyen szemlélték más régiók, mint a latin-amerikai térség nemzetközi súlyának felértékelődését. Az Európával rivalizáló latin-amerikai tömbtől tartva azok törekvéseit rendre megvétózták, vagy a szőnyeg alá söpörték. Igaz Franciaország a nemzetközi izoláció elkerülésének érdekében egy ideig kacérkodott a latin-amerikai térség támogatásával, de a Németországgal továbbra is fennálló feszült viszony miatt a francia külpolitika napirendjéről ez lekerült.

Maguk a latin-amerikai nemzetek is hátráltatták saját történelmi törekvésüket Az 1920-as évtized során Európa ügyei iránt ők sem tanúsítottak sok érdeklődést. Bár a latin-amerikai államok vezetői és népszövetségi delegáltjai a Nemzetek Szövetsége által nyújtott lehetőségekről ugyanazt vallották, és mindenkiben megfogalmazódott az, hogy a siker kulcsa az egymással való együttmúködés, ennek megvalósítása a gyakorlatban már jóval nehezebb volt. A régió országaiban továbbra is jelen volt a stabilitás hiánya. Gazdasági nehézségeik miatt pedig a népszövetségi tagság költségeit se tudták állni, ami szintén gyengítette a térség pozícióját.

Mindezek mellett a korban az Egyesült Államok külpolitikájában is irányváltás történt. A hivatalosan izolacionalista kormányzatok valójában igen aktív és gazdasági erejükre épülő diplomáciát folytattak, amelynek hatására az USA latin-amerikai térségben tanúsított intervenciós politikáját

${ }^{47}$ MCPherson, 2015. 26.o. 
is elkezdték felszámolni. Az Egyesült Államok nyomására pedig a latinamerikai országok elkezdtek visszatérni az USA „védőernyője” alá és a pánamerikai együttmúködés keretei közé. Az 1920-as évtizedtől folyamatosan megszűntek az amerikai fegyveres megszállások és protektorátusok, a Franklin Roosevelt által meghirdetett „jó szomszédság” elvének hatására pedig a második világháború végére ez a rendszer - egy időre - felszámolásra került. ${ }^{48}$

Összességében elmondható, hogy Latin-Amerika és a Népszövetség együttműködésének történelmi lehetősége a szervezet passzivitásán, az európai nagyhatalmak elutasításán, a latin-amerikaiak belső konfliktusain és az Egyesült Államok nyomására bukott meg. A latin-amerikaiak népszövetségi részvétele ettől függetlenül nem volt teljesen sikertelen. ${ }^{49} \mathrm{~A}$ régió országai az 1930-as években már egyre nagyobb aktivitás tanúsítottak a nemzetközi politikai életben és közösen léptek fel a nemzetközi válságok során. Az USA korban tapasztalható külpolitikai irányváltásában, amely a latin-amerikai államokkal szemben tanúsított viselkedésük újraértékelését is jelentette, nagyban szerepet játszott az a tény, hogy az Egyesült Államokban is felismerték, ha a latin-amerikai kapcsolataikat nem mozdítják el a történelmi mélypontról, akkor a térség országait könnyen a Népszövetség „karjaiba” taszíthatják. Ez a folyamat esélyt adhatott volna, hogy az európai nagyhatalmak újra befolyást szerezhetnek az amerikai kontinensen, aminek megakadályozása az Egyesült Államok hagyományos külpolitikai érdeke volt. ${ }^{50}$ Ennek tudatában az amerikai kormányzatok szakított az addig bevett külpolitikai iránnyal és másfél évtized lefolyása alatt a Népszövetséggel szemben, a régi-új pánamerikai együttmúködés keretében, kedvezőbb alternatívát dolgoztak ki.

\section{FELHASZNÁLT IRODALOM}

Bosco, Peter I. (2007): Amerika háborúban. Az első világháború, Debrecen, Gold Book

Burks, David D. (1959): The United States and the Geneva Protocol of 1924: „A New Holly Alliance”? The American Historical Review, Vol.64. No.4. 891-905.

\footnotetext{
48 MAgYarics, 2014. 712.o.

${ }^{49}$ Ezekről ld. MCPHERSON - WEHRLI, 2015. 83-257.o.

50 Az Egyesült Államok külpolitikai hagyományáról vö. KISSINGER, 2008. 21-46.o. MAGYARICS, 2014. 15-185.o.
} 
A latin-amerikai országok népszövetségi tagságának hatása az Egyesült Államok LatinAmerika politikájára

Clark, Christopher (2015): Alvajárók. Hogyan menetelt Európa 1914-ben a háború felé, Budapest, Park Könyvkiadó

Cannistraro, Paul (1996): Mussolini, Sacco-Vanzetti, and the Anarchist: The Transatlantic Context, Journal of Modern History, Vol.68. No.1. 31-62.

Duggan, Stephen P. (1934): Latin America, the League, and the United States, Foreign Affairs, Vol.12. No.2. 281-293.

Ewell, Judith (1996): Venezuela and the United States: From Monroe's Hemisphere to Petroleum's Empire, Athens, GA, University of Georgia Press

Fiallo, Fabio (1940): The Crime of Wilson in Santo Domingo, Havanna, Arellano

Goldberg, Jonah (2012): Liberálfasizmus. A baloldal rejtett története Mussolinitól napjainkig, Budapest, XX. Századi Intézet

Iriye, Akira (1993): The Cambridge History of American Foreign Relations. Vol.III. The Globalizing of America, 1913-1945, Cambridge, Cambridge University Press. DOI azonosító

https://doi.org/10.1017/CHOL9780521382069

Johnson, Paul (2016): Az amerikai nép története, Budapest, Akadémiai Kiadó

Kane, Stephen N. (1973): Bankers and Diplomats: The Diplomacy of the Dollar in Mexico, 1921-1924. The Business History Review, Vol.47. No.3. 335-352. DOI azonosító: https://doi.org/10.2307/3113268

Kissinger, Henry (2008): Diplomácia, Budapest, Panem Kiadó

León, Fabián Herrera: Mexico and its „Defense” of Ethiopia at the League of Nations. In: McPherson, Alan - Wehrli, Yannick szerk.: Beyond Geopolitics. New Histories of Latin America at the League of Nations, Albuquerque, University of New York Press

Macmillan, Margaret (2005): Béketeremtők. Az 1919-es párizsi békekonferencia, Budapest, Gabo Kiadó

Magyarics Tamás (2014): Az Egyesült Államok külpolitikájának története. Mítosz és valóság: Érdekek és értékek, Budapest, Antall József Tudásközpont

McPherson, Alan (2015): Anti-Imperialism and the Failure of the League of Nation. In: McPherson, Alan - Wehrli, Yannick szerk.: Beyond Geopolitics. New Histories of Latin America at the League of Nations, Albuquerque, University of New York Press 
Mengele Ferenc (1927): A Népszövetség jogi és politikai rendszere, Budapest, Franklin-Társulat

Migone, Gian Giacomo (2015): The United States and Fascist Italy. The Rise of American Finance in Europe, Cambridge, Cambridge University Press

Oñate, Abdiel (2015): Nonintervention through Intervention: Mexican Diplomacy in the League of Nations during the Spanish Civil War. In: McPherson, Alan - Wehrli, Yannick szerk.: Beyond Geopolitics. New Histories of Latin America at the League of Nations, Albuquerque, University of New York Press

Peterecz Zoltán (2008): Különös háromszög. Az Egyesült Államok, a Népszövetség és Latin-Amerika gazdasági és politikai kapcsolatai az 1920-as években, Aetas, 23. évf. 2. sz. 129-137.

Streeter, Michael (2010): Central America and the Treaty of Versailles, London, House Publishing

Szijj Jolán - Ravasz István (2000): Magyarország az első világháborúban. Lexikon A-Zs, Budapest, PETIT REAL Könyvkiadó

Taylor, A. J. P. (2011): A második világháború okai, Budapest, Scolar Kiadó United Nations Office at Geneva (2020). Elérhető: https://www.unog.ch/80256EDD006B8954/(httpAssets)/36BC4F83B D9E4443C1257AF3004FC0AE/\%24file/Historical overview of the L eague of Nations.pdf (Letöltve: 2020. április 8.)

Wehrli, Yannick (2015): New Histories of Latin America at the League of Nations. In: McPherson, Alan - Wehrli, Yannick szerk.: Beyond Geopolitics. New Histories of Latin America at the League of Nations, Albuquerque, University of New York Press 